Click www.researchjournal.co.in/online/subdetail.html to purchase.

INTERNATIONAL JOURNAL OF PLANT PROTECTION

- ISSN-0974-2670 | Visit us : www.researchjournal.co.in

\title{
Effect of organic amendments on the nutritional value of oyster mushrooms (Pleurotus spp.)
}

\author{
Julie I. Elizabeth ${ }^{1 *}$ and T. Sheela Paul ${ }^{2}$
}

${ }^{1}$ Regional Agricultural Research Station Ambalavayal, Ambalavayal, Wayanad (Kerala) India

${ }^{2}$ Department of Plant Pathology, College of Horticulture, Vellanikkara, Thrissur (Kerala) India

\section{ARITCLE INFO}

Received : 28.07 .2020

Revised : 09.09 .2020

Accepted : 23.09.2020

KEY WORDS :

Nutritional value, Crude protein, Total free amino acid, Total carbohydrate, $\mathrm{N}$, $\mathrm{P}$ and $\mathrm{K}$
*Corresponding author: Email : julie.elizabeth@kau.in

\begin{abstract}
Popularity of oyster mushroom is increasing because of its ease of cultivation, high yield potential as well as its unique nutritional value. Study with oyster mushrooms viz., Pleurotus florida, P. sajorcaju, P. eous, P. tuber-regium and Hypsizygus ulmarius revealed that the nutritional value of these mushrooms can be increased significantly when grown on paddy straw supplemented with organic amendments such as rice bran, neem cake, dry azolla, vermiwash and dry biogas slurry. In addition to increased yield, the organic supplements significantly increase thecrude protein, total free aminoacid, total carbohydrate and nutrients like N,P and $\mathrm{K}$ in oyster mushrooms. Nutrient content of the mushrooms varied with different concentrations of organic amendments used. In P. florida, H. ulmarius and P.tuber-regium paddy straw amended with dry azolla gave higher amount of crude protein content (35.4, 35.3 and 34.9, respectively). Paddy straw amended with dry azolla at 4 per cent, 6 per cent and 5 per cent, respectively recorded the maximum total free aminoacid in $P$. florida $(0.6 \%), P$. sajor-caju $(0.43 \%)$ and $H$. ulmarius $(0.56 \%)$. The major nutrient elements like $\mathrm{N}, \mathrm{P}$ and $\mathrm{K}$ content also increased with addition of organic amendments.Thus, it is concluded from the study that supplementation of rice straw with rice bran, Neem cake, dry azolla, vermiwash and dry biogas slurry has strong impact in improving the crude protein, total free aminoacid, total carbohydrate and essential mineral nutrients such as $\mathrm{N}, \mathrm{P}$ and Kcontent of oyster mushrooms.
\end{abstract}

How to view point the article : Elizabeth, Julie I. and Sheela Paul, T. (2020). Effect of organic amendments on the nutritional value of oyster mushrooms (Pleurotus spp.). Internat. J. Plant Protec., 13(2) : 180-186, DOI : 10.15740/HAS/IJPP/13.2/180-186, Copyright@, 2020: Hind Agri-Horticultural Society. 